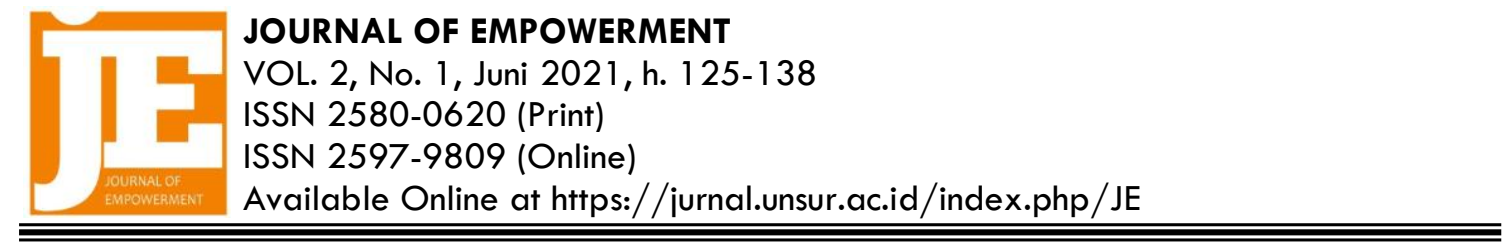

\title{
MEMADUKAN INOVASI DAN KEARIFAN LOKAL DALAM PENGAJARAN LITERASI PADA ANAK USIA DINI: PENDAMPINGAN GERAKAN LITERASI
}

\section{INTEGRATING INNOVATION AND LOCAL WISDOM IN TEACHING EARLY LITERACY TO YOUNG LEARNERS}

\author{
Nia Kurniawati', Aprilla Adawiyah², Mia Fatimatul Munsi ${ }^{3}$ \\ IUniversitas Suryakancana \\ nia@unsur.ac.id \\ 2Universitas Suryakancana \\ aprilla.adawiyah@gmail.com \\ 3Universitas Suryakancana \\ miafatimatul88@gmail.com
}

\begin{tabular}{|l|l|l|l} 
Masuk : 09 Februari 2021 & Penerimaan : 15 Maret 2021 & Publikasi : 01 Juni 2021
\end{tabular}

\begin{abstract}
ABSTRAK
Literasi dini dipandang sebagai fondasi yang sangat penting dalam perkembangan kognitif manusia, dalam pengajaran literasi Pada Anak Usia Dini (PAUD), perlu diperhatikan bahan, media, dan cara penyampaian agar anak usia dini mudah untuk memahami dan menanamkan nilai-nilai kehidupan yang terdapat dalam pembelajaran, yang dituntut untuk dapat berinovasi dan kreatif dalam menyampaikan bahan pembelajaran literasi, dalam tumbuh kembang dan karakter anak usia dini. Kegiatan ini bertujuan untuk memberikan pendampingan pada guruguru PAUD di desa Sukawangi, Warungkondang. Adapun metode kegiatan ini dilaksanakan pelatihan tentang teknik pengajaran literasi dini untuk anak-anak PAUD. Teknik yang digunakan pada para guru adalah mendongeng dengan menggunakan media boneka jari dan buku besar. Pengabdian ini bertujuan membuat guru menjadi kreatif dan anak usia dini lebih aktif terlibat pembelajaran serta mengenal kearifan lokal Cianjur.
\end{abstract}

Kata Kunci : Kearifan; Literasi; Media; Mendongeng.

\begin{abstract}
Early literacy is seen as a very important foundation in human cognitive development, in teaching literacy in PAUD, it is necessary to pay attention to materials, media, and delivery methods so that early childhood is easy to understand and instill the values of life contained in learning, which is required to be able to innovate and be creative in delivering literacy learning materials, in the development and character of early childhood. This activity aims to provide assistance to PAUD teachers in Sukawangi village, Warungkondang. The method of this activity is training on early literacy teaching techniques for PAUD children. The technique used by the teachers is storytelling using finger puppets and large books. This service aims to make teachers creative and early childhood more actively involved in learning and get to know Cianjur local wisdom.
\end{abstract}

Keywords : Local; Literacy; Media; Story Telling. 


\section{A. PENDAHULUAN}

Guru yang kreatif dan inovatif dapat menciptakan pembelajaran yang menyenangkan dan mudah dipahami siswa, terutama pembelajaran pada era globalisasi. Pembelajaran pada abad ke-21 merupakan pembelajaran yang mampu membentuk manusia yang kritis atau dalam artian dapat mengidentifikasi masalah, menganalisisnya, memberikan solusi, dan dapat membuat keputusan secara tepat pada permasalahan-permasalahan yang muncul. Membentuk manusia yang kritis, berarti harus mampu membentuk manusia yang memiliki kemampuan berbahasa dengan baik atau kemampuan berkomunikasi yang baik (Hosnan, 2016). Kemampuan berbahasa dapat diajarkan sejak dini dan termasuk salah satu perkembangan pada anak usia dini. Seperti yang dikemukakan Hurlock (dikutip oleh Sobarna, 2010) bahwa belajar berkomunikasi adalah salah satu tugas dalam perkembangan anak usia dini. Salah satu kemampuan atau keterampilan berbahasa adalah menyimak dan membaca. Dua keterampilan ini yang akan menjadi dasar dalam kemampuan berbicara dan menulis pada anak usia dini. Minat baca perlu ditanamkan sejak dini, karena dengan mengenalkan buku sejak awal, maka akan menumbuhkan kebiasaan membaca sampai dewasa. Kebiasaan membaca belum dimiliki oleh masyarakat Indonesia, bahkan anakanak saat ini lebih dekat dengan gawai atau permainan-permainan yang mengurangi minat siswa dalam membaca, terutama di Indonesia. Hal ini terbukti dari data UNESCO yang menunjukkan bawa pada tahun 2012 indeks tingkat membaca orang Indonesia hanya 0,001 . Dengan kata lain, dari 1.000 penduduk, hanya ada satu orang yang mau membaca buku dengan serius. Berarti, di antara 250 juta penduduk Indonesia, hanya 250.000 yang sudah memiliki minat membaca. UNESCO juga mengemukakan bahwa pada tahun 2014, anak-anak Indonesia hanya membaca 27 halaman dalam satu tahun. Data ini dikuatkan lagi oleh survei tiga tahunan Badan Pusat Statistik mengenai minat membaca dan menonton anak-anak Indonesia pada tahun 2012 , yaitu hanya 17,66\% anak-anak yang memiliki minat dalam membaca, sedangkan yang memiliki minat menonton mencapau $91,67 \%$. Kenyataan inilah yang membuat pemerintah mulai menggencarkan kembali gerakan gemar membaca, salah satunya dengan cara menerapkan gerakan literasi dalam pembelajaran. Apalagi jika melihat peringkat literasi Indonesia berada di posisi kedua terbawah dari 61 negara yang diteliti oleh Central Connecticut State University dalam data World's Most Literate Nations, tahun 2016 (posisi Indonesia berada di atas Bostwana dan Afrika) (Januwati; \& Ficky Yusrini, 2016). Data tersebut dapat menjadi acuan bagi para guru dalam melaksanakan pembelajaran, terutama literasi pada anak usia dini. Pada umumnya, saat ini pembelajaran literasi, masih didominasi oleh kegiatan membaca siswa. Literasi tidak dikenalkan dengan teknik dan media yang bervariasi.

Pada anak usia dini, gerakan literasi perlu diperhatikan, karena pada umumnya, anak usia dini belum mengenal tulisan atau belum bisa membaca dan menulis. Oleh karena itu, dalam pembelajaran guru perlu menyiapkan atau merancang teknik, metode, dan media yang menyenangkan bagi anak usia dini. Selain kemampuan membaca dan menulis (keterampilan), guru juga jangan sampai melupakan aspek lain yang harus diperoleh siswa, yaitu sikap dan pengetahuan. Abidin, (2015) megemukakan bahwa dalam konteks kurikulum yang terbaru (kurikulum 2013), pembelajaran bahasa ditujukan untuk mencapai empat kompetensi utama, yaitu kompetensi religius, sosial, pengetahuan, dan keterampilan. Pendidikan Anak Usia Dini merupakan pendidikan yang mengembangkan berbagai aspek perkembangan anak, mulai dari aspek perkembangan psikomotor, kognitif, perkembangan bahasa, perkembangan nilai agama dan moralserta perkembangan seni (Kunci, dikutip oleh Ramdhani, Yuliastri, Sari, \& Hasriah, 2019). 
Literasi tidak hanya befokus pada kegiatan membaca dan menulis saja. Akan tetapi, membaca dan menulis merupakan kemampuan dasar yang harus dikuasai siswa atau anak untuk memahami, mengkrtisi, dan menciptakan suatu hal, apabila minat membaca dan menulis tinggi, maka pemahaman dan pola pikir yang kritis serta kreatif akan muncul. Istilah literasi diartikan sebagai kondisi melek huruf, melek kata, dan melek makna. Tambahan pula dengan istilah melek wacana. Dengan adanya istilah melek wacana, maka makna literasi meluas (digunakan pada beberapa bidang ilmu yang terintegrasi dengan bidang kajian ilmu bahasa) (Abidin, 2015). Permatasari, Inten, Mulyani, \& Rahminawati (2017) berpendapat bahwa pada anak usia dini, literasi yang diajarkan dan dibiasakan adalah literasi usia dini atau disebut dengan emergent literacy. Clay dalam buku Desain Induk Gerakan Literasi mengemukakan bahwa literasi dini (early literacy) adalah kemampuan untuk menyimak, memahami bahasa lisan, dan berkomunikasi melalui gambar dan lisan yang dibentuk oleh pengalamannya berinteraksi dengan lingkungan sosialnya di rumah. Pengalaman berkomunikasi dengan bahasa ibu dapat menjadi fondasi literasi dasar bagi peserta didik. literasi dini memiliki ciri atau karakter khas, yaitu pembelajaran dilakukan secara informal atau anak-anak yang tidak merasa sedang dalam tugas atau keadaan belajar, semua hal yang diajarkan adalah hal-hal yang dekat dengan kehidupan anak (Kebudayaan, 2016). Kegiatan membaca bagi anak usia dini tidak hanya kegiatan membaca melalui buku, tetapi dapat juga berupa membaca lingkungan, misalnya tulisan-tulisan di lingkungan sekitar, sama halnya dengan menulis.

Gerakan literasi pada umumnya diartikan sebagai gerakan membaca dan menulis, padahal teknik dan metode pelaksanaan gerakan literasi ini dapat dilaksanakan secara bervariasi. anak usia dini adalah anak-anak yang pada umunya belum memiliki kemampuan membaca dan menulis, oleh karena itu gerakan literasi yang dilaksanakan harus dengan teknik dan metode yang lain yang mudah diterima oleh anak. Salah satu teknik gerakan literasi dan media yang digunakan adalah dengan bercerita, penggunaan boneka, dan bigbook atau buku besar. Dickinson, Jonathan, \& Shenton (dikutip oleh Anggraeni, Hartati, \& Nurani, 2019) mengemukakan bahwa metode bercerita merupakan metode yang sangat penting untuk menstimulasi anak dalam mengungkapkan dan mengembangkan imajinasinya, sehingga kemampuan berbicara dapat meningkat. Story sangat menarik untuk siswa karena berisi pengalaman yang indah, lucu, dan menarik, melalui berceritabanyak hal ang dapat disampaikan dan dipahami oleh pendengar, karena penyampaiannya yang menarik dan bahasa yang digunakan lebih sederhana (Fajriah, 2011). Bahan dan sumber yang digunakan untuk gerakan literasi juga harus diperhatikan, jangan sampai isi dari bahan atau sumber yang diberikan tidak memiliki makna atau pelajaran bagi siswa. Alangkah lebih baiknya jika, bahan dan sumber literasi dapat menumbuhkan karakter anak atau siswa, juga dapat mengenalkan siswa pada budaya, atau memiliki muatan kearifan lokal. Dengan bahan atau bacaan yang mengandung nilai kearifan lokal (khususnya Cianjur), dapat mengenalkan dan menanamkan kecintaan anak usia dini pada budaya lokal, khususnya budaya Cianjur. Mengenalkan dan mengajarkan kearifan lokal Cianjur sejak dini, dapat memberikan fondasi kuat bagi anak di tengah dampak negatif era globalisasi terhadap tergerusnya nilai-nilai kearifan lokal yang juga berpengaruh pada penanaman karakter. Hurri \& Munajat (n.d.), berpendapat bahwa kompleksitas permasalahan yang berkaitan dengan karakter atau moralitas siswa di negeri ini (khususnya Cianjur) telah menjadi keprihatinan dan perhatian semua komponen bangsa, ditandai dengan meningkatnya kejahatan tindak kekerasan, penyalahgunaan narkoba, ketidakpedulian pada niai-nilai kearifan lokal, dan dampak negatif lainnya. Hal ini senada dengan yang dikemukakan Lickona (dikutip dalam Yunus, 2014) bahwa terdapat 10 tanda dari perilaku manusia akibat kurang optimalnya pengenalan nilai- 
nilai budaya (kearifan lokal) pada masyarakat, yaitu meningkatnya kekerasan di kalangan remaja; ketidakjujuran yang membudaya; semakin tinggi rasa tidak hormat kepada orang tua, guru, dan figur pemimpin; pengaruh peer group terhadap tindak kekerasan; meningkatnya kecurigaan dan kebencian; penggunaan bahasa yang memburuk; penurunan etos kerja; penurunan rasa tanggung jawab; tingginya perilaku merusak diri; dan kaburnya pedoman moral. Negara yang mampu menjaga dan melestarikan nilai-nilai budaya (kearifan lokal) dapat berkembang dengan baik dan mampu meminimalisasi masalah-masalah sosial di masyarakat, karena itulah perlu upaya mentransformasi nilai-nilai kearifan lokal untuk pembangunan karakter bangsa agar dapat mempertahankan warisan budaya (Yunus, 2014). Selain itu, dengan menggali dan melestarikan berbagai unsur kearifan lokal, tradisi, dan pranata lokal, termasuk norma dan adat istiadat dapat berfungsi secara efektif dalam penidikan karakter, sambil melaksanakan kajian dan pengayaan dengan kearifan-kearifan yang baru (Fajarini, 2014). Hal ini senada dengan yang dikemukakan Cahyaningrum, Sudaryanti, \& Purwanto (2017) bahwa pendidikan karakter bagi anak usia dini dimaksudkan untuk menanamkan nilai kebaikan supaya dapat menjadi kebiasaan saat dewasa atau pada jenjang pendidikan selanjutnya. Wardhani (2001) mengemukakan bahwa upaya menggali, menguji, mensosialisasi dan mengkulturasi tata nilai luhur perlu terus ditingkatkan dan didukung dengan memperluas penerapan modal budaya dan modal sosial sebagai sumber yang dapat ditransformasikan menjadi nilai tambah dalam membangun dan membentuk karakter bangsa. Berdasarkan hal tersebut, pengabdian yang dilaksanakan mengenai memadukan inovasi dan kearifan lokal dalam pengajaran literasi pada anak usia dini ini, dapat menjadi alternatif pembelajaran bagi guru PAUD, agar pembelajaran literasi lebih bervariasi dan berbasis kearifan lokal, juga menjadikan guru PAUD di desa Sukawangi lebih kreatif dan inovatif menciptakan media dan mengangkat kearifan lokal Cianjur untuk gerakan literasi Anak Usia Dini.

\section{B. METODE}

Pengabdian pelatihan gerakan literasi pada guru-guru PAUD ini dilaksanakan pada tanggal 12 Agustus 2017 di SDN Sukawangi 2 Kecamatan Warungkondang Cianjur. Peserta terdiri atas para guru PAUD/RA se-Desa Sukawangi. Pengabdian dilaksanakan oleh dosen FKIP Universitas Suryakancana sebagai pemberi materi dan pelatihan, serta mahasiswa KKN Desa Sukawangi, dengan peserta pengabdian berjumlah 18 orang. Kegiatan pengabdian ini dilaksanakan dalam tiga tahapan, sebagai berikut:

\section{Diagram 1, Alir Kegiatan}

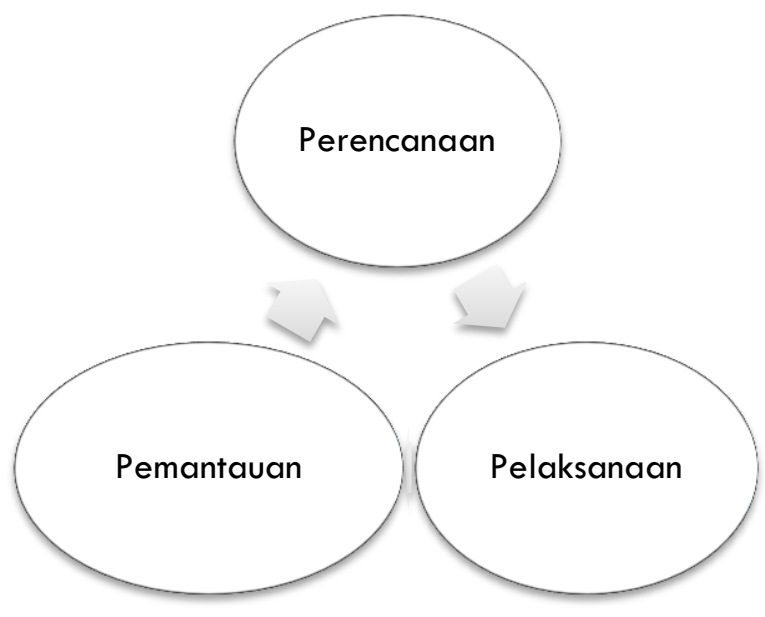


Pertama, tahap menggali informasi dan data awal tentang pelaksanaan gerakan literasi yang sudah diterapkan oleh para guru. Dalam tahapan ini, data diperoleh melalui teknik observasi dan wawancara. Observasi dilakukan untuk mengetahui kondisi awal gerakan literasi di Desa Sukawangi sebelum dilaksanakannya pelatihan. Sedangkan wawancara dilakukan untuk mendapatkan data mengenai variasi pembelajaran gerakan literasi berbasis kearifan lokal yang sudah diterapkan oleh para guru kepada peserta didiknya.

Pada tahap kedua, yaitu pelaksanaan kegiatan inti. Teknik yang digunakan pada tahap ini ialah pemaparan materi pelatihan, demonstrasi, dan bermain peran (role playing). Presentasi materi yang berkaitan dengan gerakan literasi bermuatan lokal bertujuan menambah pengetahuan awal para guru dalam literasi berbasis kearifan lokal. Kearifan lokal Cianjur perlu dikenalkan sejak dini kepada peserta didik untuk menambah pengetahuan tentang kota Cianjur dan menunjukkan jati diri siswa sebagai orang Cianjur. Hal tersebut dilakukan karena pada era globalisasi seperti sekarang, budaya asing sangat mudah masuk dan memberikan pengaruh yang kurang baik kepada generasi muda. Siswa lebih bangga dengan budaya asing daripada budayanya sendiri, sehingga dikhawatirkan budaya lokal akan terlupakan. Teknik demonstrasi dilakukan untuk memberikan gambaran mengenai pelaksanaan gerakan literasi dengan metode dan media yang bervariasi. Di antaranya dengan penggunaan media buku besar dan boneka jari. Media tersebut digunakan dalam bercerita atau story telling dan membaca cerita story reading. Selanjutnya para guru bermain peran, mempraktikkan hasil pelatihan.

Selanjutnya, tahap ketiga merupakan tahap pemantauan yang dilaksanakan seminggu setelah pelatihan, sebagai tindak lanjut pada kegiatan inti. Pada tahap ini, para guru memang telah melaksanakan gerakan literasi sebagaimana yang telah dilakukan pada kegiatan pelatihan. Dari kegiatan-kegiatan gerakan literasi inilah diperoleh produk berupa buku besar dan boneka jari hasil karya para guru. Indikator keterceapaian keberhasilan pelaksanaan pengabdian ini adalah adanya antusias guru dalam menerapkan gerakan literasi berbasis kearifan lokal.

\section{HASIL ATAU PEMBAHASAN}

Berdasarkan hasil analisis program pendampingan pengajaran literasi dini pada guruguru PAUD desa Sukawangi ini, terdapat beberapa temuan yang dipaparkan sebagai berikut:

\section{Tingkat pemahaman literasi dini dan pengajaran literasi dini di kalangan guru}

\section{PAUD di Desa Sukawangi}

Untuk mendapatkan data mengenai tingkat literasi guru PAUD di Desa Sukawangi digunakan instrumen kuisioner. Kuisioner terdiri dari 20 butir mengenai pengetahuan guru PAUD menegani anak usia dini, literasi dini dan pengajarannya dengan mengadopsi taksonomi Bloom (Krathwohl, 2002). Dari hasil kuesioner tadi didapatkan hasil sebagai berikut.

Tabel 1 Tingkat Kognisi terhadap Konsep Literasi Dini di Kalangan Guru PAUD di Desa Sukawangi Sebelum Dilakukan Pelatihan

\begin{tabular}{|c|c|c|c|c|c|c|c|}
\hline \multirow{2}{*}{ Kategori } & \multicolumn{5}{|c|}{ Level Kognisi Guru PAUD } \\
\cline { 2 - 7 } & Mengingat & $\begin{array}{c}\text { Memaham } \\
\text { ai }\end{array}$ & Adaptasi & $\begin{array}{c}\text { Mengap } \\
\text { likasikan }\end{array}$ & $\begin{array}{c}\text { Menganalisi } \\
\text { s }\end{array}$ & Mengevaluasi & $\begin{array}{c}\text { Mencipta } \\
\text { kan }\end{array}$ \\
\hline AUD & & & & & & \\
\hline $\begin{array}{c}\text { Definisi Anak } \\
\text { Usia Dini } \\
\begin{array}{c}\text { Tahap } \\
\text { perkembangan } \\
\text { AUD }\end{array}\end{array}$ & $\sqrt{ }$ & & & & & & \\
\hline
\end{tabular}




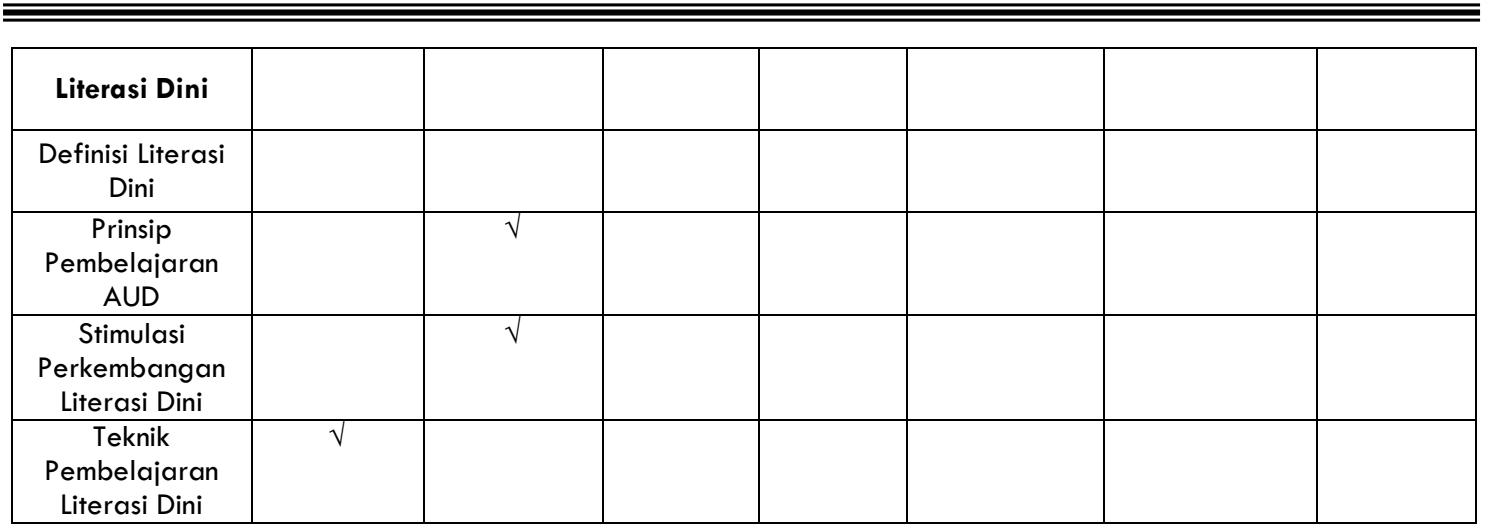

Berdasarkan tabel 1 tersebut, dapat dideskripsikan bahwa secara umum tingkat kognisi guru PAUD di Desa Sukawangi, mnegenai konsep anak usia dini dan literasi masih pada level LOTS (Low Order Thinking Skill) atau level mehamami. Pemahaman tersebut meliputi konsep anak usia dini yang dipahami oleh responden bahwa anak usia dini adalah anak yang berusia 0-6 tahun, merupakan masa anak-anak awal sebagai penutup masa bayi dan masuk dalam masa prasekolah.

Level memahami lainya yang ditunjukkan para guru PAUD di desa Sukawangi mengenai tahapan perkembangan anak usia dini dari mulai bayi (infants), toddlers (2-3 tahun), dan anak usia 3- 6 tahun yang. Namun, guru belum begitu mengetahui bahwa pada setiap tahapan dalam masa perkembangan anak tersebut memiliki karakteristik tersendiri, yang tentunya memerlukan perlakuan yang berbeda dalam pengajaran di kelas. Sedangkan untuk konsep literasi dini, guru masih pemahaman guru masih pada tahap menganggap literasi dini sama dengan literasi orang dewasa yakni kemampuan membaca dan menulis saja. Guru pun mengembangkan perangkat ajar untuk mengajarkan siswa PAUD membaca dan menulis. Hal ini juga terjadi karena tuntutan orang tua yang belum memahami makna literasi dini yang sebenarnya.

Namun para guru PAUD di Desa Sukawangi telah memahami prinsip pembelajaran anak usia dini berdasarkan pengalaman guru mengajar. Seperti yang dikemukakan dalam UU SISDIKNAS (2003) pendidikan Anak usia dini (PAUD) adalah jenjang pendidikan sebelum jenjang pendidikan dasar yang merupakan suatu upaya pendampingan yang ditujukan bagi anak sejak lahir sampai dengan usia enam tahun yang dilakukan melalui pemberian rangsangan pendidikan untuk membantu pertumbuhan dan perkembangan jasmani dan ruhani agar anak memiliki kesiapan dalam memasuki pendidikan lebih lanjut, yang diselenggarakan pada jalur formal, nonformal, dan informal. Pendidikan anak usia dini merupakan pendidikan yang diselenggarakan dengan tujuan untuk memfasilitasi pertumbuhan dan perkembagan anak secara menyeluruh untuk mengembangkan ragam potensi yang dimiliki anak.

Guru memahami bahwa pendidikan anak usia dini merupakan pendidikan yang diselenggarakan dengan tujuan untuk memfasilitasi pertumbuhan dan perkembagan anak secara menyeluruh untuk mengembangkan ragam potensi yang dimiliki anak. PAUD merupakan sebagai lembaga pendidikan yang cukup setrategis dalam mengembagkan kemampuan, membentuk watak bagi anak usia dini.Selain itu, guru juga memahami tentang stimulasi perkembangan literasi anak usia dini pada tiap tahapan perkembangan anak usia dini dari bayi hingga 6 tahun. Sedangkan, untuk teknik pembelajaran literasi dini, guru mengetahui beberapa teknik seperti misalnya mendongeng, tapi jarang dilakukan di dalam kegiatan pembelajaran literasi dini.

Berdasarkan data kuesioner, dapat dilihat bahwa pengetahuan guru-guru PAUD di desa Sukawangi mengenai konsep anak usia dini dan literasi dini masih dalam level memahami atau pada tingkat kedua (C-2). Data dideskripsikan sebagai berikut: 
sebanyak 18 guru atau 100\% memahami mengenai definisi anak usia dini, sementara mengenai tahap perkembangan anak usia dini, 17 guru (94\%) memahami, dan 1 guru (6\%) mengetahui. Pertanyaan mengenai Literasi dini, sebanyak 15 guru (83\%) memahami, sedangkan 3 guru $(17 \%)$ hanya mengetahui, mengenai prinsip pembelajaran anak usia dini, sebanyak 16 guru $(89 \%)$ memahami hal tersebut, sementara 2 guru (11\%) mengetahui. Pertanyaan mengenai stimulasi perkembangan literasi dini, sebanyak 18 guru (100\%) telah memahami konsep tersebut, sementara mengenai teknik pembelajaran literasi dini, sebanyak 12 guru (67\%) hanya mengetahui dan sebanyak 6 guru (33\%) memahami. Hal ini dapat dipengaruhi oleh latar belakang pendidikan guru. Berdasarkan hasil wawancara dengan para guru, diketahui bahwa sebagian besar guru-guru PAUD tidak memiliki latar belakang pendidikan yang cukup. Banyak guru PAUD yang hanya lulusan SMA atau bahkan SMP sehingga tidak memiliki kompetensi pedagogis dan konten yang cukup untuk menjadi guru PAUD yang profesional.

\section{Pengajaran Literasi Dini di PAUD Desa Sukawangi}

Pelaksanaan pengajaran literasi di PAUD desa Sukawangi didasarkan pada pemahaman mengenai literasi dan prinsip pembelajaran literasi. Terdapat tujuh prinsip pembelajaran literasi, yaitu literasi melibatkan interpretasi, penulis/pembicara dan pembaca/pendengar berpartisipasi dalam tindak interpretasi; literasi melibatkan kolaborasi, kerjasama antara penulis/pembicara dengan pembaca/pendengar dalam upaya mencapai pemahaman bersama; literasi melibatkan konvensi atau kesepakatan kultural (tidak universal) yang berkembang melalui penggunaan dan dimodifikasi untuk tujuan-tujuan individual; literasi melibatkan pengetahuan kultural (sistem-sistem sikap, keyakinan, kebiasaan, cita-cita, dan nilai tertentu; literasi melibatkan pemecahan masalah (adanya upaya membayangkan, memikirkan, mempertimbangkan); literasi melibatkan refleksi dan refleksi diri (penulis/pembicara dan pembaca/pendengar memkirkan bahasa dan hubungan-hubungannya dengan dunia dan diri mereka sendiri); Literasi melibatkan penggunaan bahasa baik dalam konteks lisan maupun tulis untuk menciptakan sebuah wacana/diskursus (Mujib, 2016). Abidin (2015) menjelaskan bahwa pembelajaran literasi bertujuan untuk mengembangkan tiga kompetensi utama, yaitu kompetensi pada tingkat kata, tingkat kalimat, dan tingkat teks. Istilah literasi juga dapat diartikan sebagai kata yang digunakan untuk menggambarkan kegiatan bacatulis-hitung (calistung), segala hal yang terkait dengan buku dan akses informasi, dulu literasi hanya dikenal sebagai aksara (Antoro, 2017). Sementara UNESCO memaparkan bahwa literasi bermakna praktik dan hubungan sosial yang terkait dengan pengetahuan, bahasa, dan budaya (Kebudayaan, 2016). Pemahaman para guru PAUD mengenai literasi, pada umumnya terbatas pada kegiatan membaca.

Pengabdian ini dilaksanakan pada 18 guru dari lima PAUD di desa Sukawangi. PAUD tersebut di antaranya PAUD SPS Ash-Habulyamin, PAUD SPS Cempaka, RA AIMusyawaroh, PAUD SPS Pelita Hati, dan PAUD As-Saadah.

Data yang diperoleh dari hasil observasi pada 18 guru PAUD dari lima PAUD, didapatkan gambaran mengenai teknik dan media dalam pelaksanaan gerakan literasi pada anak usia dini. Sebagian besar guru di PAUD Desa Sukawangi melakukan teknik dan metode bernyanyi, ceramah, dan klasikal pada anak usia dini, guru-guru lebih berfokus pada pembelajaran, budaya membaca masih kurang, karena guru berfokus pada pengajaran membaca. Pada kenyataannya, guru-guru mengetahui bahwa anak usia dini tidak dituntut untuk dapat membaca, tetapi orang tua siswa yang menuntut hal tersebut. Fasilitas membaca, seperti perpustakaan juga masih minim, perpustakaan hanya terdapat di satu PAUD, yaitu PAUD Pelita Hati. 
Ambarsari (2013) menjelaskan dari ahli perkembangan anak yakni Durkin dan Mentessori, anak baru bisa belajar membaca setelah anak bisa menulis dengan baik, anak harus belajar membaca dengan mendengarkan bunyi dan simbol-simbol huruf, lalu mengulanginya sampai ia benar-benar mengerti. Akan tetapi, terkadang anak bisa membaca pada saat yang bersamaan ketika anak tersebut dapat menulis. Minat adalah kecenderungan seseorang terhadap sesuatu, atau bisa dikatakan apa yang disukai seseorang untuk dilakukan. Berdasarkan data di atas, minat literasi harus dimunculkan dan ditumbuhkan sejak usia dini sehingga minat dan kecintaan anak dalam hal baca literasi akan dibawa anak sampai dewasa. Tidak bisa dipungkiri saat ini banyak ahli PAUD yang memandang pentingnya pengenalan literasi (membaca dan menulis) pada anak usia dini. Kemampuan litreasi dapat diperkenalkan atau diajarkan kepada anak usia dini sejak anak berada dalam kandungan. Tahapannya adalah bayi (infants), Anak 2-3 tahun (toddlers), anak usia 3-6 tahun (Bali, 2015).

Pelaksanaan pengabdian ini, literasi yang disampaikan melalui pembacaan cerita dengan media big book dan boneka tangan, menggunakan cerita berbasis kearifan lokal. Wibowo \& Gunawan (2015) mengungkapkan bahwa kebudayaan dan pendidikan layaknya dua sisi mata ang yang tidak dapat dipisahkan. Pendidikan dan kebudayaan merupakan satu kesatuan yang saling mendukung dan saling menguatkan. Ki Hajar Dewantara (dikutip oleh (Wibowo \& Gunawan, 2015) menjelaskan bahwa kebudayaan sebagai dasar falsafah pendidikan, sedangkan pendidikan menjadi penjaga utama kebudayaan (pendidikan berperan sebagai pembentuk orang untuk berbudaya), sehingga dapat disimpulkan pendidikan tanpa kebudayaan ibarat perahu di lautan tanpa panduan arah. Jika dikaitkan dengan gerakan literasi di sekolah, maka sangat tepat jika bahan-bahan yang digunakan dalam gerakan literasi kaya akan budaya bangsa, terutama mengangkat kearifan lokal. Kearifan lokal adalah manifestasi ajaran budaya yang dihidupkan oleh masyarakat lokal sehingga dapat dimanfaatkan sebagai penyaring masuknya interaksi budaya asing (SIHABUDIN, 2013). Dalam pembacaan cerita (story reading), para guru hanya membacakan buku cerita pada anak usia dini, tanpa mengajak siswa terlibat, buku yang digunakan merupakan buku cerita pada umumnya.

Dapat dikatakan bahwa, para guru belum terlalu memahami mengenai literasi dini dan teknik yang menyenangkan serta media yang dapat digunakan untuk mendukung pelaksanaan kegiatan Iterasi dini. Pasca pelatihan pertama (pengenalan literasi dini, teknik, metode, dan media), teknik dan media yang digunakan oleh guru PAUD masih tidak bervariasi, misalnya a) guru-guru Paud masih mendongeng atau bercerita dengan cara membacakan buku cerita (jarang memilih cerita yang bermuatan kearifan lokal), anak-anak duduk di kursi dan memperhatikan; b) saat mendongeng atau bercerita, para guru tidak menggunakan media untuk mendukung cerita, tidak berkreasi membuat media yang berkaitan dengan cerita (misalnya, boneka jari yang menggambarkan tokoh yang diceritakan); c) penggunaan media buku cerita yang tidak memadai atau buku yang digunakan tidak dapat terlihat dengan baik oleh siswa karena gambar dan ukuran buku yang terlalu kecil (dalam hal ini teknik bercerita sambil membacakan buku, sebaiknya dengan menggunakan media buku besar/big book dan pop up book). Bercerita dapat dikolaborasikan dengan bermain atau bernyanyi, karena ketiga kegiatan ini memiliki pengaruh dalam proses belajar dan perkembangan anak usia dini, termasuk pembiasaan membaca dan menulis atau kegiatan literasi. 


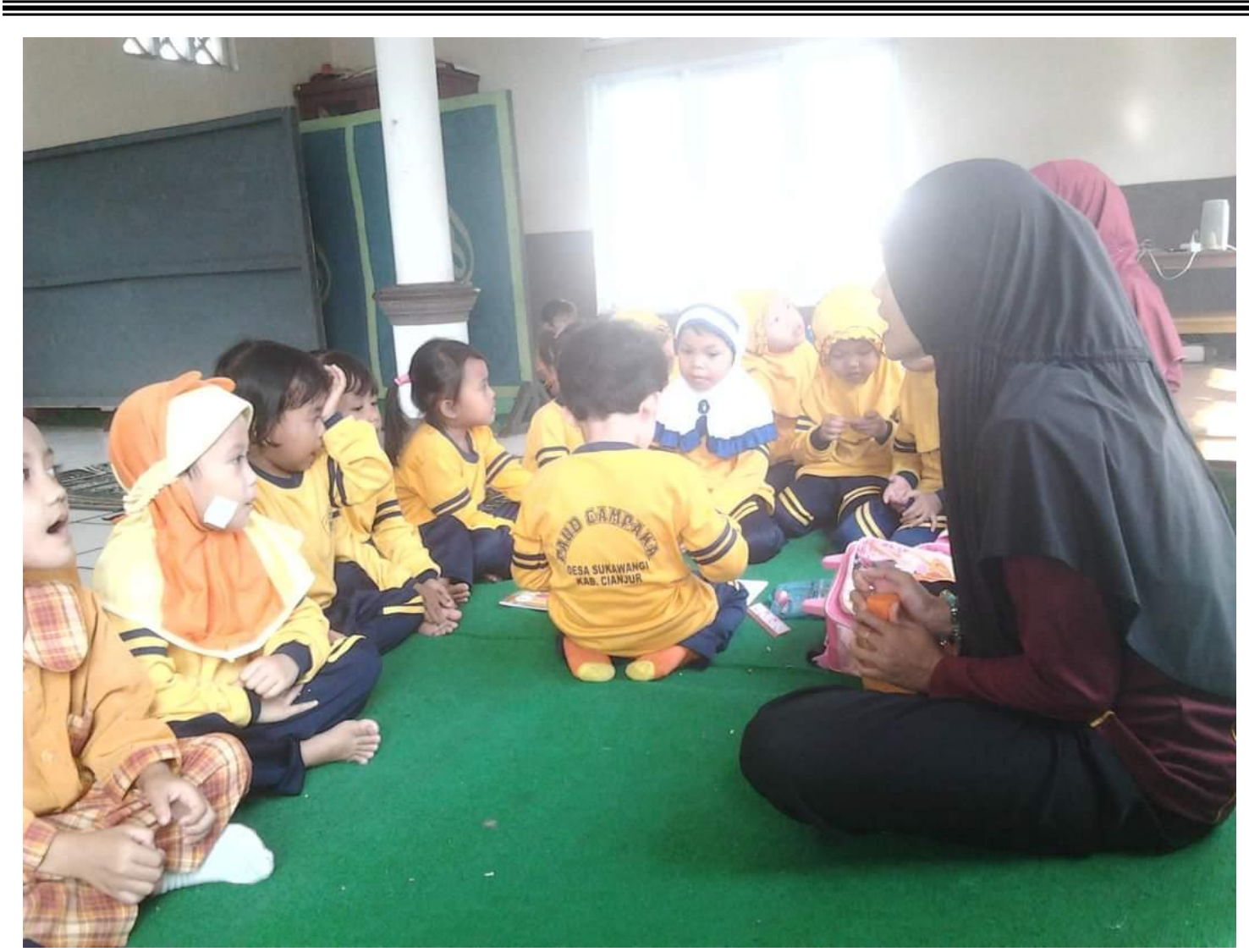

Gambar 1. Guru PAUD sedang mengajar sebelum pelaksanaan pengabdian

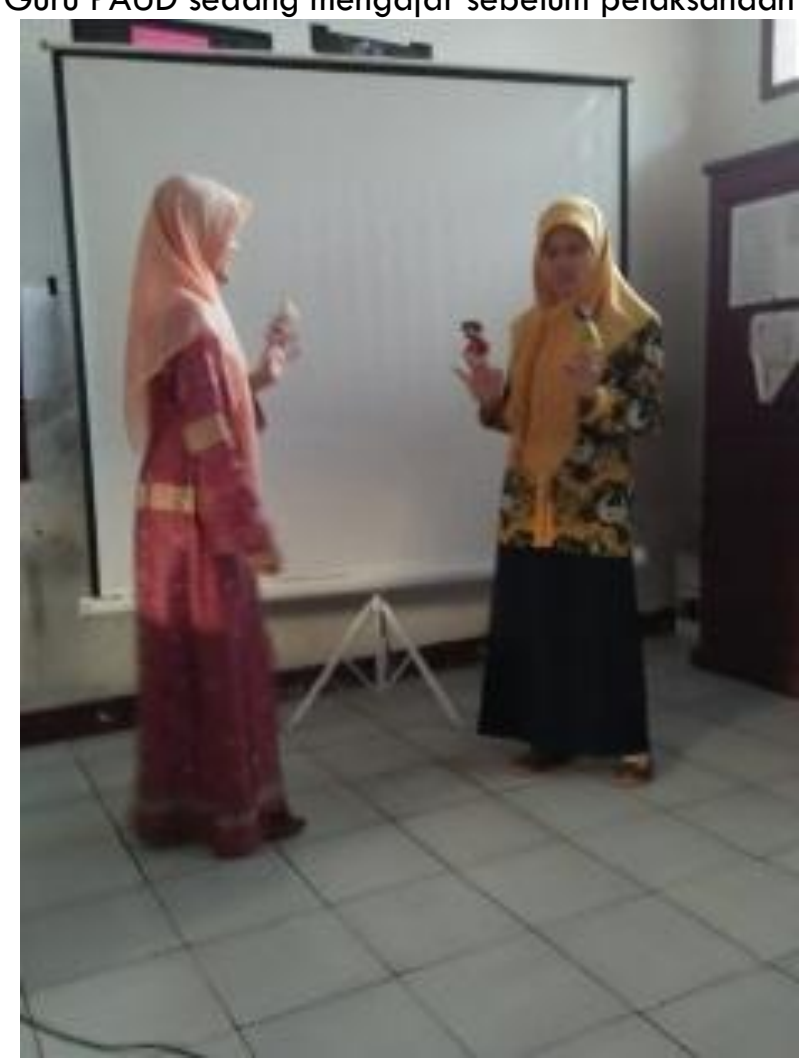

Gambar 2. Guru PAUD sedang praktik bercerita menggunakan boneka tangan

Pada kegiatan kedua, dilaksanakan pelatihan dini dengan teknik bercerita dan membacakan cerita menggunakan media buku besar (bigbook) yang didesain sebagai 
buku anak dalam versi besar dengan huruf dan ilustrasi yang juga besar, sehingga anak dapat melakukan eksplorasi terhadap teks dan mengembangkan konsep yang berhubungan dengan tulisan sebagai salah satu strategi membangun makna; boneka tangan; dan wayang. Permatasari; et al. (2017) mengemukakan bahwa Seorang anak yang memiliki minat membaca tinggi berasal dari keluarga yang memiliki kebiasaan membaca yang baik. Artinya, lingkungan rumah, sosial, dan budaya yang mengiringi tumbuh kembang anak merupakan penentu utama kemampuan literasi seorang anak. Anak dikenalkan pada kegiatan lirterasi untuk mengetahui dan memahami identitasnya, sealah satunya dapat dilakukan dalam kegiatan story telling atau bercerita/mendongeng, "story telling is a very significant part of maintining and developing their cultural values and heritage. (Mendongeng merupakan bagian penting dari upaya mempertahankan dan mengembangkan nilai dan warisan budaya). Melalui bercerita, anak dapat memperoleh informasi tentang dunia, suatu keadaan di berbagai daerah, keragaman karakter manusia, dan kebiasaan serta nilai yang dimiliki sebuah kebudayaan.

Pelaksanaan kegiatan ini dilakukan di dalam kelas, dengan cerita yang dipilih adalah cerita yang memiliki nilai karakter dan kearifan lokal. Pada kegiatan membacakan cerita, diplih buku cerita yang bermuatan karakter dengan karakter hewan berupa semut, sedangkan pada kegiatan mendongeng atau bercerita, dipilih cerita yang memiliki muatan kearifan lokal, yaitu asal-mula Cianjur. kedua cerita ini bermuatan karakter. Di dalam cerita ini, terdapat nilai budaya lokal masyarakat. Nilai budaya lokal di masyarakat inilah yang dapat dijadikan dasar atau pedoman saat masyarakat bersentuhan dengan informasi dari media asing. selain itu, budaya lokal atau kearifan lokal berkaitan erat dengan nilai-nilai karakter yang diinternalisasikan dari nilai budaya yang setiap hari anak atau siswa ketahui dan pahami (Wibowo \& Gunawan, 2015). Tahap pelaksanaannya adalah dengan :

Diagram 2, alir pelaksanaan kegiatan

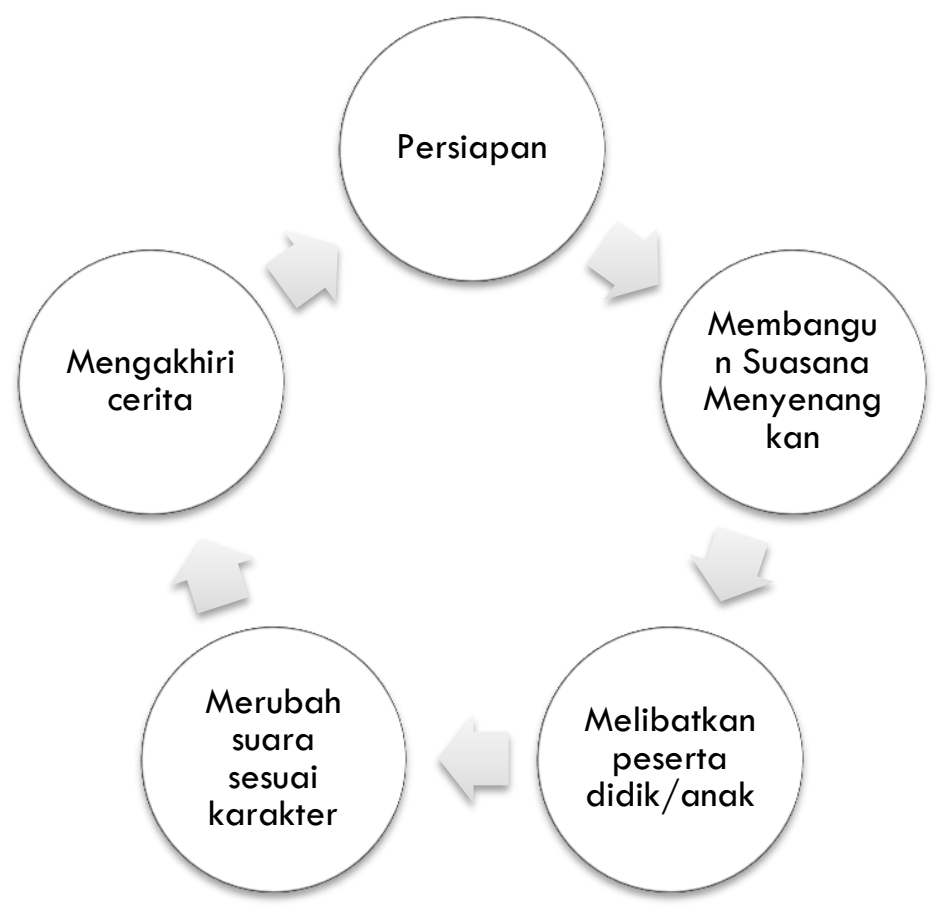

a) Persiapan (pemilihan buku cerita, big book/ buku besar dan dari video dongeng Asal-Mula Cianjur yang ditranskripsikan menjadi tulisan), dalam pelatihan 
beberapa guru memilih cerita dan media yang tidak berbeda dengan demonstrasi dari pendamping sebelumnya;

b) Membuat suasana yang menyenangkan, yaitu dengan memberikan pilihan cerita serta media yang akan digunakan, seperti beberapa buku besar dengan cerita yang berbeda dan pop up book yang berisi gambar-gambar, selain itu disediakan pula pilihan media untuk mendongeng, seperti boneka jari, boneka tangan, wayang kertas yang semuanya disesuaikan dengan karakter cerita (dibuat sendiri dan disesuaikan, di sinilah guru harus kreatif dan mau berusaha membuat medianya sendiri). Dalam membangun suasana yang menyenangkan, kalimat-kalimat yang digunakan guru dalam bercerita atau membacakan cerita haruslah kalimat-kalimat yang menarik minat anak. Misalnya, dalam membacakan cerita "lihat, ibu membawa gambar, ada yang tahu ini gambar apa?" Atau dalam mendongeng/bercerita, "siapa yang mau mendengar ibu mendongeng?" Atau "lihaat ibu bawa siapa ini di jari-jari ibu, ada yang mau berkenalan tidak?" (jika menggunakan media boneka jari);

c) Beberapa guru ada yang sudah dapat membagun suasana, ada pula yang langsung membacakan atau bercerita;

d) Melibatkan anak dalam pembacaan cerita maupun dalam bercerita, sehinga anak-anak akan merasa betah mendengarkan cerita. Guru dapat menyediakan panggung, atau mengajak anak bercerita di luar ruangan, mengajak anak bercerita dengan membuat lingkaran, dan selalu ajak anak berkomunikasi di sela cerita, misalnya dengan bertanya "siapa tadi yang menolong semut?", "lihat, ada siapa di balik batu?", "siapa ya tadi nama bapak yang pelit itu?", dan sebagainya. Dengan melakukan hal seperti itu, anak akan merasa diajak untuk masuk dalam cerita, selain itu guru juga dapat mengetahui daya serap anak terhadap cerita yang diberikan. Dalam pelatihan ini, guru berperan sebagai siswa, dan para pendamping atau pelatih mempraktikkan atau memberi demonstrasi terlebih dahulu pada guru, untuk kemudian diikuti oleh para guru. Pada kegiatan pembuka, guru mengajak anak untuk terlibat, namun untuk cerita selanjutnya, guru masih asyik berecerita dan membacakan cerita sendiri;

e) Mengubah suara sesuai dengan karakter dan menambahkan beberapa suara agar anak lebih tertarik. Misalnya, saat tokohnya nenek, maka guru dapat menyurakan suara nenek-nenek, disertai batuk, suara tokoh yang lucu, suara langkah kaki, suara pintu, dan sebagainya. Hanya terdapat dua kelompok guru yang mengubah suara pada setiap tokoh yang berbeda, meskipun hanya pada beberapa bagian, sedangkan pada bagian terakhir, guru lupa tidak membedakan suara setiap tokoh;

f) Mengakhiri cerita secara bertahap atau perlahan. Guru dapat mengakhiri cerita secara perlahan, artinya ketika cerita akan berakhir, guru dapat mengajukan pertanyaan mengenai beberapa hal berkenaan dengan cerita, menarik sebuah simpulan, pesan dan amanat yang disampaikan dalam cerita yang akan diketahui dalam akhir cerita.

\section{Respons Guru PAUD Desa Sukawangi Terhadap Kegiatan Pendampingan}

Untuk mengetahui respons para guru ini dilakukan wawancara dengan beberapa guru PAUD peserta pelatihan pengajaran literasi dini berbasis kearifan lokal ini. Wawancara dilakukan dalam suasana tidak formal dan dengan pertanyaan yang tidak terstruktur agar didapat jawaban yang natural mengenai respons guru terhadap kegiatan pelatihan seperti ini. Dari hasil wawancara ini terdapat beberapa hal menarik yang terungkap. 
Pertama, kegiatan ini dinilai sangat positif oleh para guru PAUD karena bagi banyak hal baru yang dapat dipelajari dalam kegiatan pelatihan ini seperti konsep dasar literasi dini, teknik pengajaran mendongeng dengan media, dan pemilihan dongeng yang berbasis kearifan lokal. Selama ini para guru PAUD terjebak dalam konsepsi bahwa literasi adalah kemampuan membaca dan menulis saja dan guru berkewajiban untuk mengajarkan siswa PAUD agar bisa membaca dan menulis dari sejak dini.

Kedua, rendahnya pengetahuan guru mengenai literasi bahkan konsep anak usia dini sendiri disebabkan jenjang pendidikan yang tidak memadai. Sebagian besar pengajar PAUD di desa Sukawangi berpendidikan SMA. Guru belum memiliki kompetensi pedagogis untuk menjadi seorang pengajar PAUD. Hal ini karena selama ini PAUD dianggap sebagai "sekolah-sekolahan" sehingga kualifikasi pendidikan para tenaga pengajarnya seringkali diabaikan. Padahal, PAUD merupakan pondasi yang amat penting bagi jenjang pendidikan berikutnya. Sehingga seharusnya kualifikasi tenaga pengajar PAUD juga mendapat perhatian lebih dari pemerintah dan masyarakat.

Ketiga, para guru PAUD menyepakati bahwa kegiatan pelatihan semacam ini sangat jarang dilakukan. Padahal guru-guru mengakui sangat mengharapkan pendampingan dan pelatihan agar dapat meningkatkan kemampuan dan pengetahuan dalam konsep dan teknik pengajaran anak usia dini. Jadi, guru mengakui bahwa sebelum kegiatan pelatihan ini para guru belum mengetahui dan memahami gerakan literasi apalagi literasi dini. Media yang biasa digunakan di dalam pembelajaran pun monoton karena memang fasilitas di PAUD terbatas. Namun setelah dilakukan pelatihan guru menjadi lebih kreatif dan inovatif. Para guru dapat menciptakan media sendiri sebagai alat bantu dalam pembelajaran berbasis literasi.

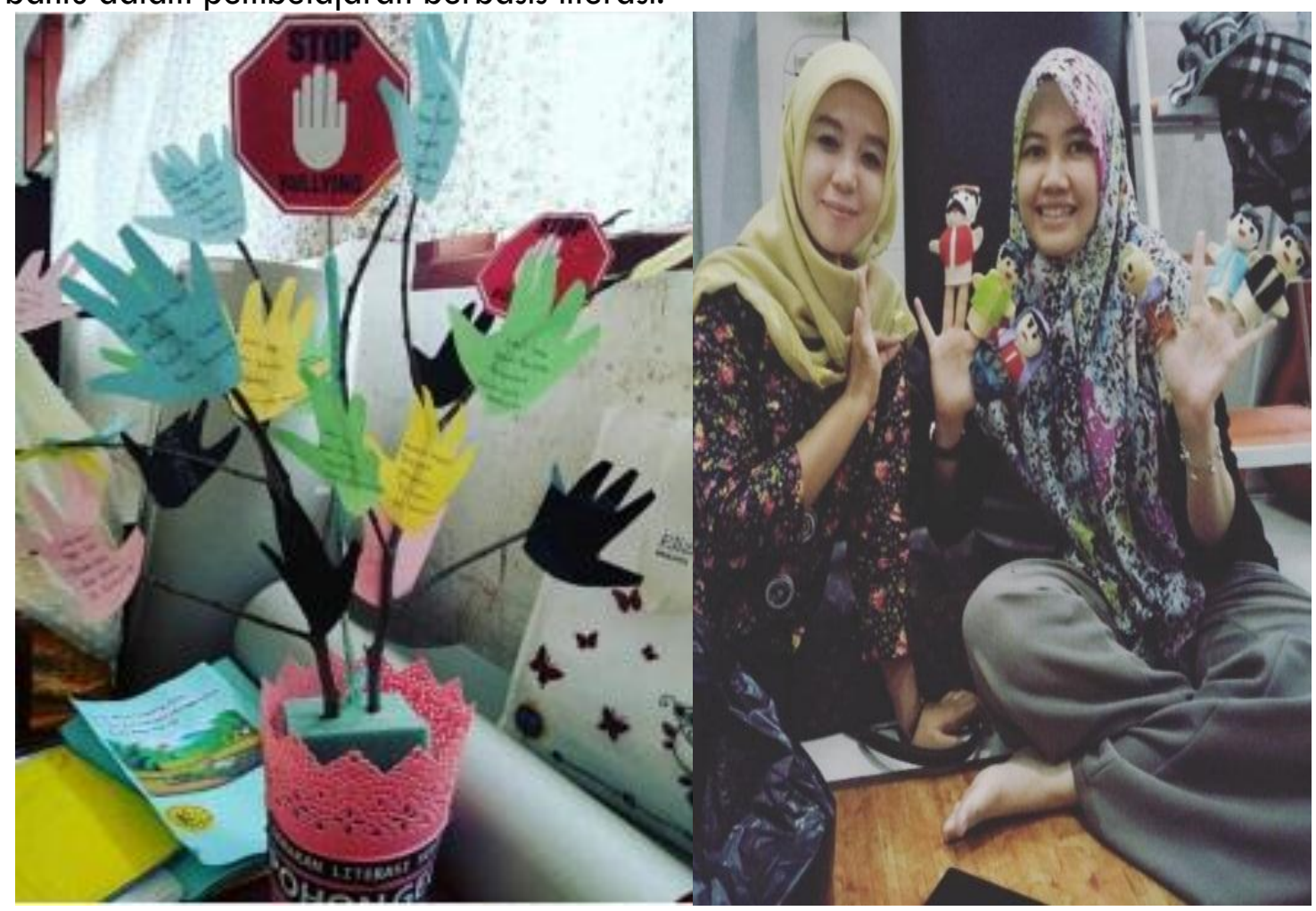

Gambar 3. Contoh media pembelajaran literasi (pohon literasi dan boneka jari)

\section{PENUTUP}

Dari kegiatan pendampingan guru-guru PAUD di desa Sukamanah ini dapat disimpulkan beberapa hal yang berkaitan dengan rumusan permasalahan yang diajukan 
sebelumnya. Pertama, tingkat pemahaman anak usia dini, literasi dini dan pembelajarannya di PAUD diketahui bahwa sebagian besar mengetahui mengenai konsep dasar anak usia dini dan literasi dini. Namun pemahaman siswa masih pada level low order thinking skill. Sedangkan untuk masalah berikutnya yakni fasilitas yang ada di lingkungan desa Sukawangi. Dalam fasilitas yang mendukung pada gerakan literasi, sebagian besar PAUD di desa Sukawangi belum memiliki peerpustakaan. PAUD yang memiliki fasilitas perpustakaan hanya PAUD Pelita Hati. Sedangkan untuk buku cerita, para guru masih menggunakan buku cerita tanpa mempertimbangkan nilai kearifan lokal di dalamnya. Namun, setelah dilakukan pendampingan para guru mulai memilih beberapa cerita yang bermuatan kearifan lokal. Media yang digunakan dalam bercerita pun masih belum bervariasi, masih ada beberapa guru yang hanya mendongeng tanpa adanya media yang membantu menstimulasi anak untuk lebih tertarik. Ketidakbervariasian media yang digunakan dikarenakan media big book, boneka jari (yang sesuai tokoh) sulit untuk didapatkan oleh guru, terkecuali guru membuat sendiri (berkreasi).

Respons para guru PAUD di desa Sukawangi secara umum sangat positif. Para guru sangat antusias mengikuti kegiatan ini karena kegiatan sejenis ini jarang dilakukan di lingkungan desa Sukawangi. Para guru PAUD di desa Sukawangi mengakui bahwa sebelum kegiatan pelatihan ini para guru belum mengetahui dan memahami gerakan literasi apalagi literasi dini. Bahkan guru dapat menciptakan media sendiri sebagai alat bantu dalam pembelajaran berbasis literasi.

Setelah pelaksanaan pengabdian gerakan literasi dini di Desa Sukawangi ini, diharapkan kegiatan serupa dapat dilaksanakan secara intensif dan berkesinambungan, dengan melibatkan berbagai pihak yang berkaitan dengan kualitas guru-guru, terutama dalam pembelajaran literasi dini. Selain media, metode, dan teknik yang diciptakan oleh guru, pembelajaran literasi ini juga perlu didukung oleh sarana dan prasarana dari pemerintah, juga hal lainnya yang dapat mendukung terlaksananya gerakan literasi. Misalnya, penyediaan buku cerita anak berbasis kearifan lokal, memfasilitasi pengembangan keterampilan guru PAUD dalam mengajarkan literasi, dan upaya-upaya lainnya.

\section{E. UCAPAN TERIMA KASIH}

Kegiatan ini tidak dapat terlaksana tanpa adanya dukungan dari beberapa pihak. Penulis ucapkan terima kasih kepada Kepala Desa Sukawangi dan guru PAUD se-Desa Sukawangi, serta para mahasiswa KKN Desa Sukawangi yang membantu terlaksananya program pendampingan dan pelatihan gerakan literasai pada anak usia dini ini

\section{F. DAFTAR PUSTAKA}

Abidin, Y. (2015). Pembelajaran Multiliterasi. Bandung: Refika Aditama.

Ambarsari, J. (2013). N. Retrieved January 30, 1BC, from http://eprints.ums.ac.id/26719/2/04._BAB_l.pdf

Anggraeni, D., Hartati, S., \& Nurani, Y. (2019). Implementasi Metode Bercerita dan Harga Diri dalam Meningkatkan Kemampuan Berbicara Anak Usia Dini. Jurnal Obsesi : Jurnal Pendidikan Anak Usia Dini. https://doi.org/10.31004/obsesi.v3i2.224

Antoro, B. (2017). Gerakan Multiliterasi Sekolah (dari Pucuk Hingga Akar, Sebuah Refleksi). Retrieved November 15, 2017, from http://eprints.undip.ac.id/21485/1/722-ki-fp-04-a.pdf.

Bali, E. N. (2015). PAUD: Pengenalan Literasi (Membaca dan Menulis) bagi AUD. Retrieved January 2018, from http://engelbertusnggalubali.blogspot.co.id/2015/11/paud-pengenalan-literasi- 
membaca.html

Cahyaningrum, E. S., Sudaryanti, S., \& Purwanto, N. A. (2017). Pengembangan NilaiNilai Karakter Anak Usia Dini Melalui Pembiasaan Dan Keteladanan. Jurnal Pendidikan Anak. https://doi.org/10.21831/ipa.v6i2.17707

Fajarini, U. (2014). Peranan kearifan lokal dalam pendidikan karakter. Sosio Didaktika, $1(2)$.

Fairiah, T. N. (201 1). Story Telling Sebagai Media Peningkatan, 1-18.

Hosnan, M. (2016). Pendekatan Saintifik dan Kontekstual dalam Pembelajaran Abad 21. Bogor: Ghalia Indonesia.

Hurri, I., \& Munajat, A. (n.d.). L o c a I wisdom v a I u e. International Seminar on Social Studies and History Education, 208-220.

Januwati;, E., \& Ficky Yusrini. (2016). Peringkat Multiliterasi Indonesia, Nomor Dua dari Bawah. Retrieved November 8, 2017, from http://www.femina.co.id/trendingtopic/peringkat-multiliterasi-indonesia-nomor-dua-dari-bawah

Kebudayaan, D. J. P. D. dan M. K. P. dan. (2016). Desain Induk Gerakan Multiliterasi Sekolah. Retrieved November 15, 2017, from http://dikdas.kemdikbud.go.id/wpcontent/uploads/2016/04/Desain-Induk-Gerakan-Multiliterasi-Sekolah.pdf

Krathwohl, D. R. (2002). Theory into Practice, A Revision of Bloom's Taxonomy: An Overview. College of Education. The Ohio State University.

Mujib, A. (2016). 7 Prinsip Dasar Literasi dan Aplikasinya dalam Pendidikan. Retrieved January 29, 2018, from http://www.wikipendidikan.com/2016/11/prinsippendidikan-literasi.html

Permatasari;, A. N., Inten, D. N., Mulyani;, D., \& Rahminawati, N. (2017). LITERASI DINI DENGAN TEKNIK BERCERITA. FamilyEdu.

Ramdhani, S., Yuliastri, N. A., Sari, S. D., \& Hasriah, S. (2019). Penanaman Nilai-Nilai Karakter melalui Kegiatan Storytelling dengan Menggunakan Cerita Rakyat Sasak pada Anak Usia Dini. Jurnal Obsesi : Jurnal Pendidikan Anak Usia Dini, 3(1), 153. https://doi.org/10.31004/obsesi.v3i1.108

SIHABUDIN, A. (2013). Literasi Media Dengan Memberdayakan Kearifan Lokal. Communication. https://doi.org/10.36080/comm.v4i2.55

Sobarna, A. Y. I. (2010). Efektivitas Metode "Storytelling" Bermedia Boneka untuk Pengembangan Kemampuan Berkomunikasi. Mimbar, XXVI(1), 71-80.

UU SISDIKNAS, Pub. L. No. 20 (2003).

Wardhani, N. (2001). Pembelajaran Nilai-Nilai Kearifan Lokal Sebagai Penguat Karakter Bangsa Melalui Pendidikan Informal. Jurnal Penelitian Pendidikan, 13(1). Retrieved from http://ejournal.upi.edu/index.php/JER/article/view/3504

Wibowo, A., \& Gunawan. (2015). Pendidikan Karakter Berbasis Kearifan Lokal di Sekolah. Yogyakarta: Pustaka Pelajar.

Yunus, R. (2014). Nilai-nilai Kearian Lokal (Local Genius) Sebagai Penguat Karakter Bangsa Studi Empiris tentang Huyula, 141. 